\title{
The Devolutionary Nature of Plato's Metaphysics Compared to Egyptian Religion, Proof of an Egyptian System of Mystery and of Grecian Origin of Speculative Philosophy
}

\author{
By Kiatezua Lubanzadio Luyaluka*
}

\begin{abstract}
The debate about the Egyptian origin of Grecian philosophy is waged so far on the ground of historicism and from the generalization of the concept of philosophy. This paper handles the issue on a theological point of view as an answer to the question: did Grecian speculative philosophy originate from ancient Egypt? Through a comparative study, the paper establishes the divergent natures of Egyptian religion and Plato's metaphysics. This divergence implies that the genesial events of Grecian speculative philosophy are not transposable on Egyptian knowledge. Moreover, both episteme do not obey equally to the epistemic evolution theorized by Auguste Comte. The paper proves the existence of a corpus of doctrines, in the religion of ancient Egypt, not found in Greece, which constitutes a system of divine mystery. However, owing to the nature of the scientificity of this corpus of religious doctrines and to the nature of their epistemology, the paper sustains that philosophy, as a speculative discipline, could not originate from ancient Egypt.
\end{abstract}

\section{Introduction}

One of the points debated in the fields of philosophy and history by Afrocentric scholars is the Egyptian origin of Grecian philosophy. Mary Lefkowitz estimates that the notion of the Egyptian origin of Grecian philosophy started during the 1920s with Marcus Garvey. However, the first published work centered on this subject was the book of Georges G. M. James ${ }^{1}$ titled Stolen legacy: Greek philosophy is stolen Egyptian philosophy; a book first published in 1954. As indicated in the title, the author argues that what the Greek call their philosophy was a paradigm already fully-formed in ancient Egypt. Thus, the Greek philosophers stole the gist of their teachings from the Egyptian mystery system and from the library of Alexandria.

The other scholar who weighed heavily on this debate is Martin Bernal. He published the three volumes of his book titled Black Athena were published respectively in 1987, 1991, and 2006. The basic argument of Black Athena is that an Aryan Model developed in $19^{\text {th }}$ and $20^{\text {th }}$ centuries prejudicially replaced the

"Director of "Institut des Sciences Animiques," Democratic Republic of Congo.

1. George M. James, "Stolen Legacy: Greek Philosophy is Stolen Egyptian Philosophy," Africology: The Journal of Pan African Studies (2009). Retrieved from https://bit.ly/31Wx69W. 
Ancient Model. While the Aryan Model claims an Indo-European origin of Grecian civilization, the Ancient Model bears witness to Greeks' epistemic borrowing from Egyptians and Phoenicians.

One of the major voices raised against the positions held by James, Bernal, and other Afrocentrists was that of Lefkowitz whose book titled Not out of Africa, contends that:

"[I]t is not true that the Greeks stole their philosophy from Egypt; rather, it is true that the Greeks were influenced in various ways over a long period of time by their contact with the Egyptians."2

Lefkowitz exposes what she estimates to be the weakness and mythological nature of the historicism used by those Afrocentric scholars she labels, due to their position,"extreme Afrocentrists." 3 Thus, she contends that the Egyptian mystery on which James grounds his affirmations were in fact of Greco-Roman origin and wrongly attributed to the Africans. As for Aristotle, she argues that he was long dead before the erection of the library of Alexandria; thus, he could not have taken his ideas there.

Against Bernal's treatment of the scholarship of Eurocentrists scholars in Black Athena, Lefkowitz deplores the facts that, according to her:

- Motives become more important than evidence.

- "Myth has now taken precedence over reality, even in the academy."4

- Symbolism becomes an approach of historical proof.

Based on a generalization of the notion of philosophy, the protagonists wage this debate so far on the ground of historicism. One may argue in favor of this generalization that the notion of philosophy and science where not then clearly separated. However, the fact is Grecians had a strong repulsion of the notion of the freedom of the soul from the body, as seen in the reluctance of Athenians to discuss its corollary doctrine, the resurrection of the dead in the beyond, with the Apostle Paul ${ }^{5}$ like other Greeks eschewed Socrates' teachings on the same notion. ${ }^{6}$

Contrary to Greeks, Egyptians stressed that freedom of the soul from the body through their iconography and by their use of oracles for judicial

2. Mary Lefkowitz, Not out of Africa (New York: New Republic and Basic Books, 1996), 161.

3. Ibid., 6.

4. Ibid., 52.

5. Acts 17: 32 .

6. Jules Dubois and Luc van den Wijngaert, Initiation Philosophique (Philosophical Initiation) (Kinshasa: Centre de Recherche Pédagogique, 1979). 
sentences and even for scientific discoveries. ${ }^{7}$ This implies that if both civilizations had the same general view of philosophy as equivalent to science, they approached the speculative practice of it from two different divergent epistemological perspectives.

We do not exclude the existence of a rationality, as a philosophy, sustaining the worldview of ancient Egyptians, as can be seen in their mastery of natural sciences and mathematics. ${ }^{8}$ In addition, we do not eschew any idea of the borrowing of the Grecian culture from ancient Egypt. However, we estimate that, as the debate goes so far, it impedes one to see in the religion of ancient Egypt more than mere myths. Moreover, it hides to the academic community the particulars and validity of the epistemology ancient Egypt shares with southSaharan Africa.

Hence, the main question for us, the one that can help us cast new light on the debate, is: was philosophy, as a speculative disciple, borrowed by Grecians from ancient Egypt? This being the case, and owing to our academic training from a Christian seminary and to our specialization as an apologist defending African epistemology and spirituality, we will lean on this debate from the point of view of theology and by restricting the concept of philosophy to the speculative practice of it. This approach imprints a new direction to the debate.

Contrary to the Eurocentric position defended by Lefkowitz, we plan to prove the existence of a corpus of doctrines in the religion of ancient Egypt, not found in Greece, which enables one to affirm the existence of a system of mystery teachings on the banks of the Nile. However, departing from the "extreme Afrocentrists," we plan to demonstrate that, owing to the nature of the scientificity of this corpus of religious doctrines and to the nature of their epistemology, philosophy, as a speculative discipline, could not originate from ancient Egyptians.

\section{Methodology}

According to Abiodun M. Jinadu ${ }^{9}$ philosophy in Greece started in $6^{\text {th }}$ century BCE and was the result of the inability of religion and myths, as mere

7. Gaston Maspero, History of Egypt, Chaldea, Syria, Babylonia and Assyria, vol. 1, part B (London: Grolier Society, 1903); Cheikh Anta Diop, Antériorité des Civilisations Nègres (Anteriority of Black Civilizations) (Abidjan: Présence africaine, 1972); Herodotus, An Account of Egypt. Retrieved from https://bit.ly/35LdMh6.

8. Théophile Obenga, La Philosophie Africaine de la Période Pharaonique (The African Philosophy of the Pharaonic Period) (Paris: Harmattan, 1990); Joseph Mabika Nkata, La Mystification Fondamentale (The Fundamental Mystification) (Lubumbashi: Presse Universitaire, 2002).

9. Abiodun Moses Jinadu, "Rethinking the Comparison between African and Western Philosophy," International Journal of Political Science and Development 2, no. 8 (2014): 180-187. 
beliefs, to answer satisfactorily the questions asked by the elite about the nature of reality. If, as implied by many Afrocentric scholars, ${ }^{10}$ philosophy as a speculative discipline started in ancient Egypt and the Grecian students took it fully-formed, then the following hypotheses can be postulated:

The Egyptians religion was a mere belief; therefore, it could not be the backbone of their scientific knowledge.

> The same genesial connection is sustainable for ancient Egypt whereby dissatisfaction with religion, as it happened with Grecian elite in $6^{\text {th }}$ century BCE, gave birth to speculative philosophy as a discipline practiced on the banks of the Nile.

$>$ Considering the same themes handled by Egyptians and Greeks, according to the epistemic evolution sustained by Auguste Comte, the later should have treated them in the same way, or in a more scientific way, due to the posterior nature of their knowledge.

The epistemology of Egyptian knowledge must be consistent with a paradigm susceptible to give rise to speculation as a discipline.

The logical disproval of all these hypotheses will mean that the notion of speculative philosophy as an Egyptian fully-formed paradigm, i.e., the Egyptian origin of Grecian speculative philosophy, is not sustainable. Therefore, the methodology of this paper will center, firstly, on a comparative study. Our comparison will gauge the Memphite theology and the metaphysics of Plato by using a cosmological argument as a common yardstick. Thus, this endeavor will include the following steps:

- We will state a cosmological argument that constitutes the systematic natural theology, a corpus of doctrines pointing toward a salvational religion. The deductive approach of this cosmological argument and its convergence with Newtonian physics will help us establish its scientificity. This will lead us to the next step, that of proving through analogical reasoning that this cosmological argument is an exact science.

- A comparative study will check whether there is a convergence or a divergence between, respectively, the religion of ancient Egypt, as stated in Memphite theology, and Plato's metaphysics both compared to our systematic natural theology, i.e., the kemetic cosmological argument (KCA).

If both episteme compare in the opposite way relative to the KCA, which is our expectation, then, based on Plato's metaphysics, the genesial connection of Grecian philosophy with religion is not transposable on the Egyptian paradigm. The divergent comparison will mean also that the epistemic

10. James, "Stolen Legacy"; Obenga, La Philosophie Africaine; Martin Bernal, Black Athena: The Afroasiatic Roots of Classical Civilization. Retrieved from https://bit.ly/2Bp0sAW; Mabika Nkata, La Mystification Fondamentale. 
evolution sustained by Comte for Western knowledge, as going from the theological stage to the philosophical one to culminate into the scientific stage, is not transposable as a hypothesized evolution of the Egyptian religion into speculative philosophy.

Thanks to the comparative study, any parallel congruence of Egyptian religion with the KCA will logically lead to the transference of the demonstrated scientificity of the KCA to the core elements of this African religion. Therefore, this scientificity of the KCA will enable us to reach the next two steps:

- From analogical reasoning we will show that, just as the rationality that is imbedded in mathematics cannot lead us to infer a speculative nature of this science, the deductive nature of the KCA, as congruent to the core elements of the religion of ancient Egypt, eschews the belief that these core elements should have consistently shrunken into a speculative philosophy.

- The revelatory nature of the epistemology of ancient Egypt will get solid rational ground thanks to the confirmation of the validity of their foundations by the KCA. This will add acumen to the argument about the Grecian origin of speculative philosophy.

The core scientific elements of Egyptian religion will enable us to affirm its Inclusion of a system of mystery teachings not found in Greece. Finally, this approach will enable us to conclude validly that the Egyptian origin of speculative philosophy is not sustainable; i.e., it is inconsistent with an epistemology that gives to induction a very low profile.

\section{The Kemetic Cosmological Argument (KCA)}

Philosophy uses cosmological argument since the book $X$ of Plato's work titled the Law. Due to its deductive approach from empirical premises, cosmological argument is the most potent way of demonstrating the existence of a creator of our temporal order. However, despite the success of the cosmological argument in demonstrating the existence of a first cause of our universe, William Rowe ${ }^{11}$ contends that, "there remains the difficult task of establishing that the first cause or self-existent being is God [the Most-high]."12

Like any cosmological argument, the KCA starts from "the presence of the cosmos back to a creator of the cosmos." ${ }^{13}$ However, transcending the

11. William L. Rowe, "Cosmological Arguments," in A Companion to Philosophy of Religion (2nd ed.), ed. Charles Taliaferro, Paul Draper, and Philip L. Quinn (Malden, MA: Blackwell, 2010), 368-374.

12. Ibid., 373.

13. Bert Thompson and Jackson Wayne, The Case for the Existence of God (Montgomery, AL: Apologetics Press, 1996), 2. 
limitation of the cosmological argument, as used in connection to Western theism, the KCA extends into a systematic natural theology that corresponds to the doctrines of a salvational religion. For the purpose of this paper, we can summarily introduce the KCA as follows:

- The contingent individual nature of this temporal universe, the visible world, appears thanks to the individualities and particular circumstances it contains.

- According to the law of causality, a necessary entity exists that, by hypothesis, includes this universe and is causative of its individual nature. Being the cause of an individual universe, this entity is individual.

- Owing to the possibilities of infinity, the individual nature of this necessary cause implies the existence of other relative necessary individual causes that are at least potentially creative.

- An absolute necessary cause exists that is the sum total of all the abovededuced relative necessary causes and is causative of their respective individualities.

- Since any temporal universe is, by hypothesis, included in its causative principle, the absolute necessary cause is the greatest possible being.

- As the greatest possible being, the absolute necessary cause is the Most-high God. Thus, the Supreme Being is absolutely in an absolute manner, without any contingence, transcendent, immutable, and indivisible. Because, any lesser nature would invite the existence of a cause greater than the greatest possible being, an impossibility.

- Due to the indivisible nature of the Most-high, each relative necessary cause, as his manifestation, expresses his wholeness. Let us call this fullness the Word.

- From the indivisibility of the Supreme Being it follows that the Most-high (the Father-Mother), the relative necessary being (the Child of God) and the Word are inseparable in their substance, existence and activity. They constitute a trinity.

- According to this trinity, the Most-high acts through the Child of God thanks to the Word. The Child always acts for the Father-Mother thanks to the Word.

- It follows from our trinity that, according to the absolute transcendence of the Father-Mother, there remain two entities that participated directly to the creative process: the creator (a Child of God) and the Word. Thus, the Word was the creative power acting in the Child of God.

- Since the celestial realm, the consciousness of the Most-high, is without any contingence, the temporal order cannot appear in it. Moreover, the existence of this order outside the Most-high would deny his absolute non-contingent infinity. Therefore, the temporal universe is only a limited perspective on the celestial realm. However, this limitation of the celestial order is illusory; because, owing to his absolute nature, the Most-high includes all reality. Thus, the temporal order is a mere appearance of celestial perfections.

- By expressing his fullness in each Child of God, the Most-high expresses infinite love to an infinite number of Children of God; thus, he is Love, the Principle of love. Being absolutely without any contingence, the Most-high cannot deprive the Child of God of the Word; thus, the Father-Mother is eternally loyal to the Child of God. It follows then that expressing the nature of truth (i.e., loyalty) to an infinite number of Children of God, the Most-high 
is Truth, the Principle of truth.

- As infinite Love and Truth, the Father-Mother has endowed the Child of God with free will, as an expression of true love.

- It follows that the bad use of the free will by a Child of God leads to his fall in the darkness and chaos of a potential temporal universe. For, by the bad use of the free will, the Child has turned away from the indivisible celestial order and light. This is the case due to the absolute immutable nature of the celestial realm; the same accounts for the illusory nature of the fall; i.e., the fall appears only in the false consciousness of the fallen Child of God, and not in that of the transcendent Supreme Being. The fall is a kind of dream.

- The annihilation of the fallen Child of God is impossible; otherwise, the absolute immutable Most-high will undergo a relational change. Therefore, the fallen Children of God abide in the potential universe as non-incarnated spirits until the loving act of the creator helps them get out of chaos and darkness.

- It thus clearly appears that the act of creation is soteriological. Being in an absolute manner absolutely immutable, God never violates the free will of the human being (the fallen Child of God); it follows that, aside from the operation of the Word, the salvation of mortals depends also on their own acceptation of the offer of divine Love through sanctification. This is the case because sin, which reduces the Word to a mere potential state (i.e., the fall), must be vanquished.

\section{The KCA as a Systematic Natural Theology}

From what has been summarily developed above, the reader senses that there is a systematic natural theology that includes, in a peculiar way, at least the following doctrines of theology: a theology proper, a doctrine of the Word, a doctrine of trinity, a doctrine of creation, a cosmology, an anthropology, and results is a soteriology.

On the level of theism, the KCA teaches the existence of one and only one absolute necessary being. All lesser beings are only his manifestations. We label this theism hierarchical monotheism. The top of this hierarchy includes the Mosthigh, the creator, and the Word. The Child of God manifests the fullness of the infinite glory of the Father-Mother; therefore, he is a "sun."

The KCA has revealed that creation appears in the temporal consciousness of the creator, and is the direct work of two principles: the creator and the Word. Creation is not ex-nihilo; since it tails a state of potential being where all temporal entities (fallen Children of God) and their lesser expressions already exit, but as non-incarnate spirits.

As for the temporal universe, the KCA has revealed its nature as a mere appearance of the celestial reality. The temporal universe is illusorily limited. However, the illusory nature pertains not to the good that appears in the temporal consciousness, because its substance is God, Spirit. The illusory 
nature applies to the limitation that the temporal perspective tries to affix on a celestial reality that is necessarily infinite.

On the soteriological level, the KCA constitutes the doctrines of a salvific religion. Salvation, i.e., victory over sin, is firstly the result of the omnipresent activity of the Word. However, since God never violates the free will of human beings, salvation requires the conscious acceptation of the free offer of divine Love through sanctification as the purification of being, the destruction of sin.

\section{On the Validity of the KCA}

The KCA is a deduction from an empirical basis: the existence of individualities and the law of causality. About deduction, James Ladyman affirms that, "it is not possible for the premises all to be true while the conclusion is false." 14 Now, the existence of individualities in our temporal universe is obvious. One can deny it only by having a view contrary to ours; however, this amount to having an individuality different from ours. Thus, to deny the existence of individuality is to give a proof of it.

The second premise of the KCA is the law of causality. The only possible objection against this law is that it does not account for quantum phenomena. However, this objection does not apply to the KCA because, there is a mathematical proof that this argument results in a cosmology that explains the wave/particle dilemma of quantum physics in a deterministic way. ${ }^{15}$ This, explains why Einstein predicted that, "beneath the chaos of the quantum might lie hidden a scaled-down version of the well-behaved, familiar world of deterministic dynamics."16

The second proof of the validity of the KCA is the mathematical cogency of the cosmology that results from it as a Newtonian explanation of the dynamics of the universe (gravitation, rotation, translation and the equilibrium of the atoms). ${ }^{17}$ We can introduce this cosmology this way:

- Creation happens on the highest intermediary temporal plane. This is the case because the celestial level is immutable, thus the creator cannot leave it. Moreover, the creator cannot descend lower than the highest intermediary level; otherwise, he will be like a fallen Child of God.

- The presence of the intermediary plane implies that in any created universe,

14. James Ladyman, Understanding Philosophy of Science (London: Routledge, 2002), 264.

15. Kiatezua Lubanzadio Luyaluka, "Religion and Science Conversion Possibility: Towards the Formulation of a Systematic Theodicy of African Traditional Religion and its Reinterpretation of Empirical Cosmology," Africology: The Journal of Pan African Studies 7, no. 7 (2014): 108-139.

16. Werner Heisenberg, Physics and Philosophy (New York: Penguin Books, 1989), xi.

17. Luyaluka, "Religion and Science Conversion Possibility." 
there are more than one temporal plane of existence and they all exist in the temporal consciousness of their creator. Therefore, there is an absolute spacetime and relative spaces-times. The first includes the second ones. The relative spaces-times are the ones where the perceptions of temporal beings unfold directly. Thus, to each temporal plane corresponds a relative space-time.

- According to its definition of the temporal universe, the KCA implies that the descent of the creator into the higher intermediary plane entails an illusory limitation of his consciousness, kind of lucid dream.

- The celestial plane being without contingency, and owing to the illusory nature of the limitation of reality, the creator is moving back to the celestial consciousness under the impulse of the omni-active and omnipresent Word.

- Stirred by a constant power, i.e., by the Word, the move of the creator to the omnipresent celestial reality is an isotropic acceleration. This acceleration necessarily translates into the isotropic acceleration of the absolute space-time into nothingness.

- The acceleration of the absolute space-time toward nothingness leads to the simplest explanation of the dynamics of the temporal universe at the astronomic and subatomic levels in a Newtonian deterministic way.

It is provable that the acceleration of the creator induces also the acceleration of our relative space-time toward infinity. However, this last acceleration is so weak that we will consider it as negligible in the following calculus.

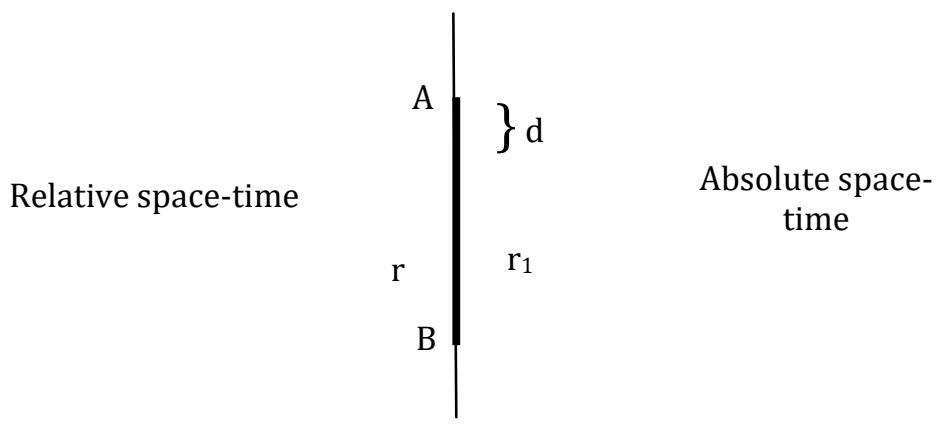

Let $A$ and $B$ be two points at the intersection of the absolute space-time and our relative one. The distance $\mathrm{AB}$ measured in both spaces-times is respectively: $r_{1}$ and $r$. We must meet two conditions: the acceleration of $r_{1}$ toward nothingness and its appurtenance to the absolute space-time.

At the initial moment, seen from the point $B$, the situation is in accordance with the equation: $r_{1}=r$ (1). As time elapses, our observer placed at point $\mathrm{B}$ witnesses the loss of the distance $d$ by $r_{1}$. We get $r_{1}=r-d$ (2). By writing $d$ as a factor of $r$, we have $r_{1}=r-r . k$ (3), with $0 \leq \mathrm{k} \leq 1$. Thus, as $r_{1}$ accelerates toward nothingness, the factor $k$ accelerates toward 1 . The equation of the accelerated rectilinear movement of $k$ is $k=k_{0}+v_{0} t+\frac{1}{2} g t^{2}(4)$. With the initial magnitude and velocity of $k$ both null, this equation becomes $k=\frac{1}{2} g t^{2}$ (5). Thus, the equation (3) becomes $r_{1}=r-r \frac{1}{2} g t^{2}$ (6). By a double derivation of 
the equation (6), we get the value of the acceleration of $r_{1}$ according to the time of our relative space-time, i.e., the time of our watches: $a=-r g$ (7).

For the second condition, we have to express the appurtenance of $r_{1}$ to the absolute space-time, i.e., to a volume of this space-time. Let us consider a prism having $r_{1}$ as the measure of the sides of its square base. According to (1) we have $v_{1}=h r^{2}(8)$. By writing $\mathrm{h}$ as a factor of $\mathrm{r}$ we have $v_{1}=q \cdot r^{3}(9)$. From (9) we get $r=\frac{v_{1}}{q r^{2}}$ (10). The exact height of the prism does not influence the calculation; thus, $\frac{v_{1}}{q}$ can be a constant c to get $r=\frac{c}{r^{2}}$ (11). By replacing (11) in (7) one gets $a=-\frac{c g}{r^{2}}$ (12). With $-c g=G$, we finally get $a=\frac{G}{r^{2}}$ (13). Now by multiplying both sides of the equation (13) by the respective masses of the celestial bodies symbolized by the points A and B one gets: $F=G \frac{M m}{r^{2}}$. This is an easy explanation of Newton's law of gravitation according to KCA by using elementary notions of analysis and kinematics. This is the mathematical validation of the KCA.

\section{The KCA as an Exact Science}

From the preceding, we conclude that the KCA is a valid logical reasoning; i.e., its scientificity is obvious. Therefore, our concern here is to answer the following question, "is the KCA an exact science?"

From an operational point of view, we can start by looking at what makes of mathematics an exact science. Liaqat Khan alludes to two elements as leading to the exactness of mathematics: its deductive approach and its coherence or consistency. Speaking about the later characteristic, he explains, "no theorem of the system contradicts another." 18

Therefore, an exact science starts from general premises taken as valid and proceeds by deductive reasoning to result in a body of coherent statements. It results also from mathematics that such a body of knowledge has possible applications in other fields of knowledge.

The KCA starts from general premises (the existence of individualities in our temporal universe and the law of causality) taken as valid. From this basis, the KCA proceeds by deduction and results in a body of knowledge, a systematic natural theology. This corpus is consistent because each statement unfolds deductively from the previous one. It is also applicable to the field of

18. Liaqat Khan, "What is Mathematics - An Overview," International Journal of Mathematics and Computational Science 1, no. 3 (2015): 98. 
cosmology for the explanation of the dynamics of the universe in a simple holistic approach, a "theory of everything."

Therefore, we have solid ground to conclude that our systematic natural theology is an exact science. The KCA constitutes the gist of divine Science, a deductive and consistent explanation of the nature of God, of the temporal universe, and of the relationship of God with his manifestations.

\section{The KCA and the Memphite Theology}

The question we are going to answer here is, "how does the KCA compare with the theology of the religion of ancient Egypt, especially the Memphite one?" The world know Memphite theology thanks to the Shabaka Stone, an inscription saved by the Nubian pharaoh Shabaka and thought to be originally "written in the $28^{\text {th }}$ Dynasty (ca. 1539-1292 BCE)."19

The comparative study of our systematic natural theology, the KCA, and the religion of ancient Egypt reveals the following convergent elements:

- The existence and transcendence of the Most-high: the Pyramid text of Unas bears witness to the existence of the notion of the Most-high in ancient Egypt. This book speaks of him as the "Sole Lord."20 Moreover, the Papyrus of Ani (usually called the Egyptian book of the dead) speaks implicitly of him as the "Lord One" and alludes to the creator ( $\mathrm{Ra}$ ) as a son of Nut (the heaven); thus, revealing explicitly a higher order in comparison to which Ra is a demiurge. Georges Rawlinson ${ }^{21}$ affirms the transcendence of the Most-high God as his being never named, nor represented. To this, Archibald H. Sayce adds the consequential fact that ancient Egyptians never addressed prayers to him..$^{22}$

- The solar nature of the relative necessary beings: the KCA reveals the Child of God as a "sun." This means an expression of the fullness of the glory of the indivisible and infinite Most-high, fullness that we called the Word. The same nature appears in Memphite theology by the name Ra (Sun) affixed to each demiurge.

- Two creative principles: James sustains the existence of two principles in Memphis directly involved in creation (the creator and the Word). ${ }^{23}$ The creator is Atom. "Atom, having absorbed the thought and creative power of Ptah, then proceeds with the work of creation."24 This confirms that the Word

19. Wim Van den Dungen, The Memphis Theology. Retrieved from https://bit.ly/2MXY Wvg.

20. Ibid., text no. 171.

21. George Rawlinson, Ancient Egypt (BiblioLife, 2009), chapter II, §24.

22. Archibald Henry Sayce, The Religion of Ancient Egypt and Babylonia. Retrieved from https://bit.ly/2BjGI1P.

23. James, "Stolen Legacy."

24. Ibid., 74. 
acts in the creator, in accordance with the trinity dictated by the KCA, as the creative power.

- The hierarchy of divinities: the existence of a transcendent Most-high (the Sole Lord), of a creator (Atom) who "sits upon Ptah" (an indication of a higher hierarchical position), added to the existence in each district of ancient Egypt of a "dead God,"25 a divinized ancestor, implies a hierarchy of divinities.

- The nonexistence of a personal Satan: the KCA reveals the transcendence and absolute non-contingency of the Most-high; this conception excludes the existence of a personal adversary of God. The notion of Satan, an adversary of God, does not exist in the religion of ancient Egypt. The near candidate to this office is the Egyptian god Set. However, it is said of him, "Horus purifieth Set and Set strengtheneth, and Set purifieth and Horus strengtheneth."26 This teaching of the Papyrus of Ani implies that Set is not entirely malevolent as Satan is.

- The existence of many creative principles: the existence of an infinity of creators (actually or potentially causative), as the relative necessary causes of the KCA are, is attested of the Egyptian religion by the Papyrus of Ani. This book clearly designates the creator, $\mathrm{Ra}$, as "the firstborn of the primeval gods," but affirms also the presence of "the Company of the Firstborn Gods." Clearly, the existence of these others "firstborn Gods" does allude to their own actual or potential creative orders different from the universe of Atom. The figure 1 depicts their existence as suns in the heavenly consciousness, the body of Nut. The plurality of creative principles is clear also in the Egyptian affirmation of the plurality of the worlds. ${ }^{27}$

- Creation as occurring in the consciousness of the creator: we know that in ancient Egypt the priests avoided to name or represent the Most-high. ${ }^{28}$ Therefore, the body of Nut in figure 1 represents the celestial consciousness. It follows that, like the demiurges are seen as suns in the body of Nut (the celestial consciousness), creation is represented as reeds in the body of Geb (the consciousness of the creator).

- The potential existence before creation: speaking of the Egyptian cosmology, Cheikh Anta Diop affirms that "at the origin there is an uncreated chaotic matter: the noun."29 Théophile Obenga calls the noun, "a matter uncreated but 'able' to become the matter of the creation." ${ }^{30}$ The KCA reveals that, prior to the act of creation the fallen Children of God exist in a dark and chaotic potential temporal universe.

- The divinity of the human beings: according to the KCA, the apparent nature of the temporal world and the inseparability of human beings with the Word (due to the absolute immutability of the Most-high) implies that the true nature of human beings is the divine, the Word. The body is a mere appearance. Obenga

25. Maspero, History of Egypt, Chaldea.

26. Wallis Budge, The Egyptian book of the dead (Great Britain: The Medici Society LTD, 1913).

27. Diop, Antériorité des Civilisations Nègres.

28. Rawlinson, Ancient Egypt.

29. Diop, Antériorité des Civilisations Nègres, 217.

30. Obenga, La Philosophie Africaine, 35. 
affirms this fact by signaling that in ancient Egypt "man is properly god."31

- Salvation through the Word and through sanctification: the Papyrus of Ani affirms this soteriological doctrine of ancient Egypt. In this book, the dead Osiris Ani claims the right to be an Osiris (a Child of God); this he does on the ground of the purity of his past life; he vanquished sin on earth. This claim implies that, up to now, he was an Osiris only potentially, i.e., sin has reduced his divine nature to a mere potential state. The advocate of Osiris Ani is Horus, arguing for him that "His heart is righteous, and it hath come forth from the Balance; it hath not sinned against any god or any goddess."32 The papyrus calls Horus "dweller in Hearts, in the Dweller in the body." This recalls the presentation of the Word as the manifestation of the fullness of God in human beings and Gods, the divinity that abides in them. Thus, Horus is the temporal expression of the Word. We learn here that, like the KCA, the Egyptian religion teaches salvation through the Word and through sanctification.

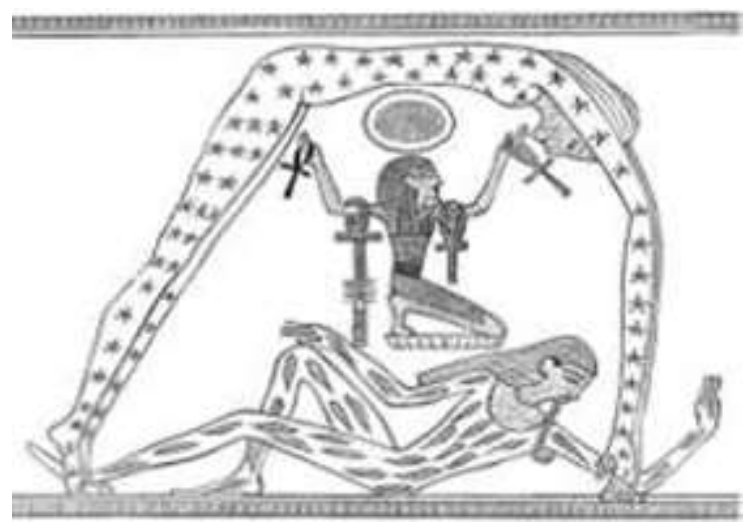

Figure 1. The Nut, Shu, Geb Scene

Source: https://bit.ly/2VQXrD7.

From all the points evoked above a parallel convergence emerges between the essential points of the religion of ancient Egypt as salvational, and our systematic natural theology. This means that the core of this African religion is a corpus of scientific knowledge that constitutes an exact science.

One of the questions that arise here is, "were the ancient Egyptians aware of the presence of a corpus of divine Science in their religion?" The congruence of the KCA with the texts and iconographies of this civilization leads us to opine that the answer to this question must be an affirmative one. However, the important thing is not the one of knowledge of the scientific nature of this corpus their teachings, but of its practice.

Henry Smith Williams informs us: "all Egyptian science is eminently practical."33 Now, the Papyrus of Ani attests the practice of divine Science. This

31. Obenga, La Philosophie Africaine, 101.

32. Budge, The Egyptian book of the dead..

33. Henry Smith Williams, A History of Science. Retrieved from https://bit.ly/2VRj cmh. 
book illustrates this practice as the practice of divine Science, as a doctrine of salvation used by an Egyptian initiate to develop his divinity, i.e., to become an Osiris, a Child of God. Let the reader notice that:

- Ani is called Osiris while claiming the right to be an Osiris, i.e., he was Osiris, a Child of God, only potentially due to sin.

- As the divinity abiding in Ani, Horus is the temporal manifestation of the Word.

- Horus is the advocate of Ani.

- Horus pleads that Ani lived a life of sanctity.

It thus then clearly appears that the scheme of salvation used here is consonant with the deductions of the KCA: salvation by means of the Word and sanctification. Therefore, we infer that ancient Egyptians the ancient Egyptian knew the existence and import of this corpus of divine Science.

Moreover, the insistence of ancient Egyptians on the freedom of the soul from the body ${ }^{34}$ illustrates their faith in revelation and deduction (reasoning from God to man) as the highest means of acquisition of knowledge. This conviction transpires in the fact that ancient Egyptians used oracles even for the discovery of scientific truths..$^{35}$ Thus, we have ground to sustain that these Africans attributed a great enlightening potential to their religion as a revelation having the value of the highest truth. The presence of myths does not weaken this affirmation. Because, either they were they were necessary either for the contextualization of the scientific religious truths in particular aspects of their culture or needed to hide the true import of divine teachings to foreign inquisitive students, as we will see later.

\section{The KCA and the Metaphysics of Plato}

Contrary to the Egyptian theology, whose systematic nature appears in its congruence with the KCA, the eclectic metaphysical doctrines of Plato are not an organized corpus of knowledge and are found dispersed throughout his works. According to Aleksandar S. Santrac, these doctrines "had a significant influence on the development of the Christian doctrine of God." 36 Thus, it is interesting to study the nature of Plato's teachings about theism, the noumenon, and the phenomena in comparison with the KCA and Memphite theology, considering the congruence of the later with this systematic natural theology.

34. Maspero, History of Egypt, Chaldea.

35. Herodotus, An Account of Egypt.

36. Aleksandar S. Santrac, "Three I Know not What: The Influence of Greek Philosophy on the Doctrine of Trinity," Die Skriflig/In Luce Verbi 47, no. 1, Art. \#719: 2. 


\section{Plato's Theism}

History depicts teaches us that the customary notion of God among the Greeks as anchored in anthropomorphic polytheism; However, the elite instructed about the mysteries of nature reasoned differently from the populace. Xenophanes said about this situation: "many gods exist according to custom but only one true God exist according to nature." 37 Therefore, "Plato's highest idea was strictly monotheism, although he presented it in his own way."38

The metaphysical ideas of Plato have influenced the Christian notion of theism. Santrac affirms of this that "according to some church fathers, Plato's idea of a Good (the Idea of the Good) has been recognized as analogous with the notion of a Christian God." 39 To this notion of the idea of Good, Plato added the concept of the demiurgic creator. One of the characteristics of Plato's demiurge is that, contrary to the KCA, he is the same with the Logos (the Word). However, Plato added to his top two divinities a third one that he called the Psyche or the world Soul. ${ }^{40}$

Through the mouth of Hermogenes, Plato defines Psyche as the power "which carries and holds nature."41 This concept of the "soul of nature" inspired the Christian notion of the Holy Ghost. Thus, as adopted by the Church, the concept of the "soul of nature" led to the Christian notion of trinity as including the Father (the idea of Good) the Son (the creator who is also the Logos) and the Holy Ghost. Eleonore Stump defines Christian trinity is this way:

According to the doctrine of the Trinity, God is three persons but only one substance; the persons of the Trinity are distinguished from one another only by relational attributes and not by any intrinsic essential or accidental properties, all of which are identical among the three persons. ${ }^{42}$

Stump estimates that this notion of trinity is not reconcilable with the doctrine of the simplicity of God. The difficulty involved in the Christian notion of trinity is the called the "logical problem of trinity," alluding to it, Michael J. Murrray \& Michael Rea say:

"The doctrine of the Trinity appears, on the surface, to be logically contradictory (...) there are at least initially persuasive reasons for thinking that no being could possibly be both fully human and fully divine, as well as reasons for thinking

37. Kenneth Scott Latourette, A History of Christianity (San Francisco, CA: Harper \& Row, 1980), 98.

38. Ibid., 92.

39. Santrac, "Three I Know not What," 2.

40. James, "Stolen Legacy"; Santrac, "Three I Know not What."

41. Plato, "Cratylus," in Plato Complete Works. Retrieved from https://bit.ly/2qwMGKy.

42. Eleonore Stump, "Simplicity," in A Companion to Philosophy of Religion (2nd ed.), ed. Charles Taliaferro, Paul Draper, and Philip L. Quinn (Malden, MA: Blackwell, 2010), 273. 
that the doctrine of the incarnation as it is traditionally understood is logically untenable."43

Contrary to this intricate Plato-inspired Christian trinity, the trinity drawn from the KCA is the natural deductive result of the transcendent and indivisible nature of the Most-high God. It helps explain the presence of two distinct creative principles (the Creator and the Word or Logos).

Thus, Plato's concept of monotheism evidences a complete deviation from the simple deductive creative theism of the kind of religion dictated by the KCA. Plato's monotheism results in a devolution from a scientific religious episteme toward a speculative theism. The adoption of Plato's theism in Christianity resulted finally in the concept of the Most-high-creator a notion in which "God turns out to be a logically impossible being." 44

\section{Plato on the Apparent Nature of Phenomena}

One of the convergences of Plato's metaphysics with the KCA is the perception of the phenomena of this visible universe as mere appearances of the superior world of pure essence, the world of ideas. James affirms this truism in his own way, "the noumen is real and perfect; but the phenomenon is unreal and imperfect." ${ }^{45}$ Emeka C. Ekeke explains this idea in this way:

"Plato also held the view that there are two worlds; the visible world and the invisible world. The visible world is the shadow of the real world. He further stressed that reality is not temporal, but it is spiritual and eternal."46

From the KCA this notion of the apparent nature of the visible world is the deductive result of the absolute non-contingency of the Supreme Being and of the fact that creation occurs in the temporal illusory consciousness of the creator. The finale result of this concept of the temporal universe in cosmology is the simple mathematical deterministic explanation of the dynamics of the universe at the astronomic and subatomic levels, a holistic "theory of everything."

Though Plato clearly affirms the apparent nature of our temporal world, he does it as a mere philosophical intuition. Handled this way, this notion became a mere speculation soon abandoned by the scientific community of the

43. Michael Murray and Michael Rea, An Introduction to the Philosophy of Religion (Cambridge, UK: Cambridge University Press, 2008), 64.

44. Chad Meister, Introduction to Philosophy of Religion (London, England: Routledge, 2009), 52.

45. James, "Stolen Legace," 52.

46. Emeka Charles Ekeke, "The Greco-Roman and Jewish Contributions to the Growth of Earliest Christianity," American Journal of Social Issues and Humanities 3, no. 1 (2014): 30. 
West. Contrary, the Egyptian affirmation of the same nature of the phenomena perdures up to now. Felicia Omotosho signals its presence among the Yoruba of Nigeria. ${ }^{47}$ In addition, the ethnography of Placide Tempels shows that the Bantu ethnics of Katanga in Democratic Republic of Congo apply this doctrine to the nature of human beings. ${ }^{48}$

Moreover, speaking of the phenomenon, Plato explains in the Sophist, "What we call an image is in reality really unreal." Contrary, the KCA depicts the phenomenon not as being unreal, but its apparent limitation of the reality, which is spiritual, is. In other words, the good appearing in the phenomenon has its substance in the Most-high, the all-in-all; hence, this rules out its unreality. Therefore, Plato does not handle the phenomenon in a scientific way as the KCA, a deductive consistent reasoning, does. Plato's metaphysics, compared to the systematic natural theology, is in reality a deviation from divine Science.

\section{The Doctrine of Opposites}

The doctrine of opposites is one of those the Greek philosophers took from Africa according to the "extreme Afrocentrists". However, the use these philosophers make of it rather deviates from the one it has in the religion of ancient Egypt. According to James, in ancient Egypt "these opposites are equivalent to the male and female principles in the cosmos." 49

Now, the unity of the female and the male is, in many African theologies, a manifestation of the completeness of God, the Word. Alluding to this malefemale nature in Bukôngo, Kôngo religion, André Fukiau sustains that it is expressive of the divine completeness of the human being. This completeness (the Word) is the manifestation of the original male-female nature recognized to Gods. ${ }^{50}$ In conformity to the KCA, this completeness originates from the indivisible unity of the transcendent Supreme Being.

Aside from symbolizing the divine completeness of being, ancient Egyptians understood opposites also as the cycle of lunar and solar thinking taking turn every 3,000 years. Persians referred to this cycle as the God of light and the God of darkness taking turn after 3,000 years. ${ }^{51}$ Ancient Egyptians used to

47. Felicia Omotosho, "A Critique of the Question of African Philosophy," IOSR Journal of Humanities and Social Sciences 19, no. 7 (2014): 61-66.

48. Placide Tempels, La Philosophie Bantoue (Bantu Philosophy) (Elisabethville, Belgian Congo: Lovania, 1945).

49. James, "Stolen Legacy," 46.

50. Bunseki Lumanisa Fukiau, Le Mukôngo et le Monde qui l'entourait (The Mukongo and the World Surrounding him) (Léopoldville, Democratic Republic of Congo: Office National de la Recherche et du Développement, 1969), 112.

51. Constantin-François Volney, Les Oeuvres de C. F. Volney (The Works of C. F. Volney) (Vol. I) (Paris, France: Parmantier \& Froment, 1826). 
name the solar phase of this cycle "the return of the Osiris from the Amenti."52 Solar and lunar thinking are two different expressions of the the reality of this visible universe, the first (used in south-Saharan Africa) sees it as being ultimately spiritual, while for the second (a paradigm used in the West) it is material.

Plato's philosophy destroys this Egyptian perception of opposites as manifesting the completeness of the same divinity and as two different epistemic expressions of the same reality. This fact is illustrated by this dialogue of his personages in Protagoras, "And that which is done in opposite ways is done by opposites? Yes." What we have from the Greek philosopher is a dualistic doctrine of opposites coming from opposite principles. Moreover, contrary to the malefemale unity, Plato sustains in Symposium a unity by disunion "like the harmony of the bow and the lyre"; while the male-female nature implies a unity by the indivisible essence of God.

Let us add that the KCA rules out duality. This argument describes God as the transcendent ultimate reality and evil as an illusory limitation of reality. If evil were real, its reality would be added to the Most high God who already includes all reality; this is a contradiction. Moreover, due to the indivisibility of God, a real evil would be part of his essence, and would result in a Supreme Being infinitely good and infinitely evil, which is logically impossible. Thus, the duality of evil and good crystallizing later in the notion of Satan is absent in Egyptian religion and in Bukôngo. Alluding to this reality in Bukôngo Joseph van Wing ${ }^{53}$ shows that Nkadi Ampemba (the devil) is not a personal being but as an attitude.

\section{The Doctrine of the Transmigration of the Soul}

There are authors, like Archibald Henry Sayce, ${ }^{54}$ who deny the existence of the doctrine of transmigration of the soul in the religion of ancient Egypt. "There was no passage of an individual soul from body to body, from form to form." 55 The transcendence of Most-high dictated by the KCA sustains that the apparition of human beings in the temporal planes is the result of their own bad use of their free will. Therefore, the natural law that governs the evolution of the soul is the law of the progression back toward the celestial realm thanks to the Word and to the purification of being. This is in conformity with the temporal and illusory nature of evil dictated by the KCA through its soteriology.

This law of progression toward infinity is the very teaching of the Papyrus

52. Rawlinson, Ancient Egypt, chapter II, §26.

53. Joseph Van Wing, Etudes Bakôngo (Studies of the Bakôngo) (2nd ed.) (Brussels, Belgium: Librarie Falk fils, 1956).

54. Sayce, The Religion of Ancient Egypt.

55. Ibid., 243. 
of Ani, where the Osiris Ani, because he lived a life of purity, claims the right to become an Osiris, i.e., the manifest Child of God he has been before his fall. This law is the very opposite of the law of reincarnation on which Plato insists in the Republic. Plato's doctrine of reincarnation teaches the tenfold retribution of sin which results in a span of a thousand years in the higher transitional world before the transmigration of the soul to the lower realm. From the deductive doctrine of the progression of the soul back to the celestial realm, through purification, to the speculative doctrine of reincarnation the trend is clearly devolutionary.

It appears clearly from this survey of Plato's metaphysics that handled by him the themes of Egyptian religion, of its central corpus that is a divine Science, becomes mere speculation and lose their scientificity evidenced thanks to the KCA.

\section{Consequences of the Divergent Nature of Plato's Metaphysics and Egyptian Religion both Compared to the KCA}

As we said above, philosophy, as a speculative discipline started in Greece in $6^{\text {th }}$ century BCE out of the inability of religion and myths, as mere beliefs, to answer questions asked by inquisitive elite about the nature of the noumenon and phenomena. The demonstrated existence of a divine Science forming the core element of the religion of ancient Egypt, leads to the following consequences:

- The scientific nature of this core element, as divine Science or a set of deductive and consistent divine teachings, is in harmony with the fact that religion in ancient Egypt was the backbone of all knowledge. Joseph Mabika Nkata puts it this way: "all sciences and all inventions are (...) linked to religion and to moral."56 Iamblichus confirms this point by informing us of Egyptian priests that "Science and philosophy were included in their teachings as being Sacred Learning." 57

- The genesial connection that led to the rise of speculation philosophy in Greece applies not to ancient Egypt. Because, its basis was the fact that Helenian religion and myths were mere beliefs. Whereas, as we have seen, the religion of ancient Egypt includes a corpus of deductive coherent doctrines, a divine Science. This science explains the nature of the noumenon and of phenomena in a deductive way. Why then should Egyptian priests speculate about the nature of God, while they knew that divine Science, as a divine revelation, provides a finale answer to this question?

- The generalization of the theory of the evolution of species of Charles Darwin to

56. Mabika Nkata, La Mystification Fondamentale, 188.

57. Iamblichus, Theurgia or On the Mysteries of Egypt. Retrieved from https://bit.ly/ 2MzfPx8. 
the fields of humanities led to the formulation by Auguste Comte of the theory of the epistemic evolution of humanity from the theological stage, where it sought illumination in religion, to the philosophical stage, were humanity resorted to speculation, and culminated in the scientific stage. This theory gave Comte the hope of the replacement of religion by sociology, by science. ${ }^{58}$ Since Egyptian religion imbeds divine Science, Comte's theory cannot apply to it.

\section{On the Existence of Mystery Teachings in Egypt}

One of the contentions of Lefkowitz is that "the notion of an Egyptian Mystery System is a relatively modem fiction, based on ancient sources that are distinctively Greek, or Greco-Roman."59 The claim here is that what Afrocentrists call "Egyptian mystery system" is in fact a Greco-Roman invention.

The KCA pointed to the existence in ancient Egypt of a corpus of scientific teachings that constitutes the core of its religion. The presence of this divine Science on the banks of the Nile weakens the position defended above by Lefkowitz. Moreover, according to Comte's theory of epistemic evolution, it is more rational to opine that Plato took the essence of his metaphysics from ancient Egyptians rather than the contrary, because from the later to the former their scientific import is lost.

As to underpin this conclusion, Lefkowitz admits the existence of "a few general common themes" 60 shared by the Egyptian religious texts and Greek philosophical writings. However, the devolutionary nature of the treatment of these themes in Plato's metaphysics implies that the Egyptian priests kept their scientific import from inquisitive Grecian students. This affirmation is in harmony with the following remark of Lefkowitz, "The notion that the Egyptian religion involved mysteries originated with the Greeks who visited Egypt and had difficulty understanding what they were shown."61

Obviously, the Grecian students had difficulty to render the scientific import of the Egyptian divine Science deliberately kept from them. This fact justifies the dilatory maneuvers used by Egyptian priests such as the necessity imposed on foreign students to master human mystery before learning divine science, and the excessive length of time it took these inquisitive minds in their attempts to learn divine Science. Pythagoras, for instance, spent 19 years

58. Roger Finke and Rodney Stark, "The Dynamics of Religious Economies," in Handbook of Sociology of Religion, ed. Michele Dillon (Cambridge, UK: Cambridge University Press, 2003).

59. Lefkowitz, Not out of Africa, 92.

60. Ibid., 157.

61. Ibid., 93. 
in this attempt, ${ }^{62}$ while according to Diop ${ }^{63}$ the same attempt took Plato 13 years.

The word mystery comes from the Greek musterion: "a derivative of 'muo' (to shut the mouth); a secret or 'mystery' (through the idea of silence imposed by initiation into religious rites): - mystery." 64 Thus, ancient Greeks perceived mystery as secret teachings leading to illumination. This is consonant with the fact that the priests kept their sacred teachings from inquisitive foreign students, but also consonant with the fact that these teachings led the Egyptian initiate Osiris Ani to become an Osiris, i.e., to reach a greater illumination.

Therefore, it is reasonable to sustain that ancient Egypt included a system of mystery which originated not from Greece, as its scientific import is lost when its themes are treated by Plato, and which was deliberately kept from inquisitive Grecian students.

\section{Why Speculative Philosophy Could Not Originate in Ancient Egypt}

In their efforts to depict Grecian philosophy as stolen from ancient Egypt, and owing to their generalization of the notion of philosophy, Afrocentrists imply that speculative philosophy started from the banks of the Nile. This position is counterproductive and is an epistemological impossibility.

We know that Euclidean geometry is an exact science. This nature of this branch of mathematics is justified by its deductive approach and the consistency of its theorems. This scientificity of Euclidean geometry precludes one from consistently reducing it into a speculative discipline. This is even more the case as speculation relies mainly on induction contrary to Euclidean geometry.

Likewise, the deductive and consistent nature of the core doctrines of the religion of ancient Egypt, seen through their parallel convergence with the KCA, precludes one from consistently reducing them into a system of speculative philosophy.

Moreover, if as affirmed in La Philosophie africaine de la période pharaonique by Obenga, "philosophy well remains an effort of man toward [emphasis is ours] an ordered thought," 65 speculative philosophy could not develop on the banks of the Nile, i.e., thought could not tend "toward an ordered thought" as it always started from divine Science. This is even more the case as all

62. Daniell Hemmert and Alex Roudène, Métempsycose, Réincarnation et Survie (Metempsychosis, Reincarnation and Life in the beyond) (Genève: Farmot, 1983). According to Diop (Antériorité des Civilisations Nègres, 98) Pythagoras spent 22 years in Egypt.

63. Diop, Antériorité des Civilisations Nègres, 101.

64. James Strong, Dictionary of the Greek Testament (Nashville, Tennessee: Abingdon, 1977), 49

65. Obenga, La Philosophie Africaine, 73. 
Egyptian sciences were "linked to religion and to moral."66 Moreover, the KCA has revealed that the core doctrines of Egyptian religion are a systematic corpus, while the teachings of Plato are not.

The insistence of ancient Egyptians on the freedom of the soul from the body, coupled to their use of oracles even for scientific discoveries as well as for judicial sentences, implies that the Egyptian concept of reason was revelatory. This epistemological conception is justified by the KCA. This argument demonstrates that:

- All reality is in God.

- Any truth is included in a knowledge of God who is all-in-all.

- Reality is ultimately spiritual.

- The material is only a limited perception of the spiritual.

Such an epistemological position gives to induction a very low profile. Therefore, speculation as scientific discipline could not arise in ancient Egypt, i.e., the priests could not speculate on the nature of a truth whose perfection they knew they could only and easily reach through revelation or deduction.

This revelatory perception of reason is still characteristic of traditional knowledge in south-Saharan Africa, where the Kôngo people when alluding to a new thought say, "an idea came to me," i.e., came from higher planes. The Yoruba of Nigeria also sustain the same perception of reason. ${ }^{67}$

The maintenance of this epistemology in south-Saharan Africa implies that the insistence of Afrocentrists on the Egyptian origin of Grecian speculative philosophy deprives the Blacks of the scientific justification of the paradigm that still characterizes the most potent of their traditional technologies. This is the case because it is not possible to account for these technologies through Western science. These technologies include for instance:

- The building of pyramids.

- Laparotomy and reduction fractures by osteosynthesis. ${ }^{68}$

- Successful cesarean performed in traditional Uganda. ${ }^{69}$

- Healing of a double fracture of the femur in five days..$^{70}$

- The observation of Sirius B by the Dogon; "a star so small, so dense, so difficult to perceive with bare eyes."71

66. Mabika Nkata, La Mystification Fondamentale, 188.

67. Pius Oyeniran Abioje, "Divine Revelation in Christianity and in African Religion: A Comparative Analysis," in Decolonization of Biblical Interpretation in Africa, ed. Samuel O. Abogunrin (Nigeria: Nigerian Association for Biblical Studies, 2005), chapter 26.

68. Obenga, La Philosophie Africaine.

69. Diop, Antériorité des Civilisations Nègres.

70. Luyaluka, "An Essay on Naturalized Epistemology of African Indigenous Knowledge," Journal of Back Studies 47, no. 6 (2016): 497-523.

71. Obenga, La Philosophie Africaine, 297-298. 
- And so on.

These feats of African traditional knowledge are justifiable only thanks to to the reliance of the Blacks on the freedom of the soul, and on an epistemological perception that counts on the fact that reality is ultimately spiritual. Because, it results from this scientific paradigm that spirits govern phenomena. ${ }^{72}$ Thus, the Afrocentists neglect of this epistemology contributes to deprive south-Saharan Africa of an ability to produce and justify an impressive technology.

\section{Conclusion}

The debate about the Egyptian origin of Grecian philosophy is waged so far on the ground of historicism and from the generalization of the concept of philosophy. In this paper, we handled the issue from the theological point of view as an answer to the question, "did Grecian speculative philosophy originate from ancient Egypt?"

To answer this question, we first stated the kemetic cosmological argument (KCA), an argument that constitutes the systematic natural theology of a salvational religion. Capitalizing on an operational definition of mathematics as an exact science, we demonstrated that the KCA is a set of deductive consistent truths having an application in the domain of cosmology, which indicates that it is an exact science.

A comparative study, taking the KCA as a yardstick, revealed a perfect convergence between the core salvific elements of the religion of ancient Egypt and this systematic natural theology while the metaphysical teachings of Plato diverge completely from the same yardstick.

It then appeared that the genesial connection from which Grecian religion and myths, as mere beliefs, led to speculative philosophy is not transposable on Egyptian religion. For, this one imbeds core elements that are convergent with the KCA, an exact science.

Moreover, the epistemic evolutionary process theorized by Auguste Comte as the progression of humanity from a theological stage, to a philosophical one to culminate into a scientific stage cannot be applied on the epistemic evolution of ancient Egypt. This is the case owing to the scientific nature of the core elements of Egyptian religion; a religion perceived as the backbone of all the knowledge of ancient Egypt.

Therefore, Contrary to the Eurocentric position defended by Lefkowitz, we proved the existence of a corpus of secret doctrines in the religion of ancient Egypt, not found in Greece, which enables one to affirm the existence of a system of mystery teachings on the banks of the Nile.

72. Luyaluka, "An Essay on Naturalized Epistemology." 
However, departing from the "extreme Afrocentrists," we demonstrated that, owing to the nature of the scientificity of this corpus of religious doctrines and to the nature of their epistemology, philosophy, as a speculative discipline, could not originate from ancient Egypt. The contrary position is counterproductive for the Blacks and is an epistemological impossibility.

\section{Bibliography}

Abioje, Pius Oyeniran. "Divine Revelation in Christianity and in African Religion: A Comparative Analysis." In Decolonization of Biblical Interpretation in Africa, edited by Samuel O. Abogunrin. Nigeria: Nigerian Association for Biblical Studies, 2005.

Bernal, Martin. Black Athena: The Afroasiatic Roots of Classical Civilization. Retrieved from https://bit.ly/2Bp0sAW.

Budge, Wallis. The Egyptian book of the dead. Great Britain: The Medici Society LTD, 1913.

Diop, Cheikh Anta. Antériorité des Civilisations Nègres (Anteriority of Black Civilizations). Abidjan: Présence africaine, 1972.

Dubois, Jules, and Luc van den Wijngaert. Initiation Philosophique (Philosophical Initiation). Kinshasa: Centre de Recherche Pédagogique, 1979.

Ekeke, Emeka Charles. "The Greco-Roman and Jewish Contributions to the Growth of Earliest Christianity." American Journal of Social Issues and Humanities 3, no. 1 (2014): 30.

Finke, Roger, and Rodney Stark. "The Dynamics of Religious Economies." In Handbook of Sociology of Religion, edited by Michele Dillon. Cambridge, UK: Cambridge University Press, 2003.

Fukiau, Bunseki Lumanisa. Le Mukôngo et le Monde qui l'entourait (The Mukongo and the World Surrounding him). Léopoldville, Democratic Republic of Congo: Office National de la Recherche et du Développement, 1969.

Heisenberg, Werner. Physics and Philosophy. New York: Penguin Books, 1989.

Hemmert, Daniell, and Alex Roudène. Métempsycose, Réincarnation et Survie (Metempsychosis, Reincarnation and Life in the beyond). Genève: Farmot, 1983.

Herodotus. An Account of Egypt. Retrieved from https://bit.ly/35LdMh6.

Iamblichus. Theurgia or On the Mysteries of Egypt. Retrieved from https://bit.ly/2MzfPx8.

James, George M. "Stolen Legacy: Greek Philosophy is Stolen Egyptian Philosophy." Africology: The Journal of Pan African Studies (2009). Retrieved from https://bit.ly/31w X69W.

Khan, Liaqat. "What is Mathematics - An Overview." International Journal of Mathematics and Computational Science 1, no. 3 (2015): 98.

Ladyman, James. Understanding Philosophy of Science. London: Routledge, 2002.

Latourette, Kenneth Scott. A History of Christianity. San Francisco, CA: Harper \& Row, 1980.

Lefkowitz, Mary. Not out of Africa. New York: New Republic and Basic Books, 1996.

Luyaluka, Kiatezua Lubanzadio. "An Essay on Naturalized Epistemology of African Indigenous Knowledge." Journal of Back Studies 47, no. 6 (2016): 497-523.

"Religion and Science Conversion Possibility: Towards the Formulation of a Systematic Theodicy of African Traditional Religion and its Reinterpretation of 
Empirical Cosmology." Africology: The Journal of Pan African Studies 7, no. 7 (2014): 108-139.

Mabika Nkata, Joseph. La Mystification Fondamentale (The Fundamental Mystification). Lubumbashi: Presse Universitaire, 2002.

Maspero, Gaston. History of Egypt, Chaldea, Syria, Babylonia and Assyria, vol. 1, part B. London: Grolier Society, 1903.

Meister, Chad. Introduction to Philosophy of Religion. London, England: Routledge, 2009.

Moses Jinadu, Abiodun. "Rethinking the Comparison between African and Western Philosophy." International Journal of Political Science and Development 2, no. 8 (2014): 180-187.

Murray, Michael, and Michael Rea. An Introduction to the Philosophy of Religion. Cambridge, UK: Cambridge University Press, 2008.

Obenga, Théophile. La Philosophie Africaine de la Période Pharaonique (The African Philosophy of the Pharaonic Period). Paris: Harmattan, 1990.

Omotosho, Felicia. "A Critique of the Question of African Philosophy." IOSR Journal of Humanities and Social Sciences 19, no. 7 (2014): 61-66.

Plato. "Cratylus." In Plato Complete Works. Retrieved from https://bit.ly/2qwMGKy.

Rawlinson, George. Ancient Egypt. BiblioLife, 2009.

Rowe, William L. "Cosmological Arguments." In A Companion to Philosophy of Religion (2nd ed.), edited by Charles Taliaferro, Paul Draper, and Philip L. Quinn, 368-374. Malden, MA: Blackwell, 2010.

Santrac, Aleksandar S. "Three I Know not What: The Influence of Greek Philosophy on the Doctrine of Trinity." Die Skriflig/In Luce Verbi 47, no. 1, Art. \#719: 2.

Sayce, Archibald Henry. The Religion of Ancient Egypt and Babylonia. Retrieved from https://bit.ly/2BjGI1P.

Strong, James. Dictionary of the Greek Testament. Nashville, Tennessee: Abingdon, 1977.

Stump, Eleonore. "Simplicity." In A Companion to Philosophy of Religion (2nd ed.), edited by Charles Taliaferro, Paul Draper, and Philip L. Quinn. Malden, MA: Blackwell, 2010.

Tempels, Placide. La Philosophie Bantoue (Bantu Philosophy). Elisabethville, Belgian Congo: Lovania, 1945.

Thompson Bert, and Jackson Wayne. The Case for the Existence of God. Montgomery, AL: Apologetics Press, 1996.

Van den Dungen, Wim. The Memphis Theology. Retrieved from https://bit.ly/2MXYWvg.

Van Wing, Joseph. Etudes Bakôngo (Studies of the Bakôngo) (2nd ed.). Brussels, Belgium: Librarie Falk fils, 1956.

Volney, Constantin-François. Les Oeuvres de C. F. Volney (The Works of C. F. Volney) (Vol. I). Paris, France: Parmantier \& Froment, 1826.

Williams, Henry Smith. A History of Science. Retrieved from https://bit.ly/2VRjcmh. 
